\title{
Krakowska oprawa księgi Jana Korzboka Witkowskiego ze zbiorów Archiwum Archidiecezjalnego w Gnieźnie ${ }^{1}$
}

Streszczenie. W komunikacie zaprezentowano oprawę zbioru listów św. Hieronima ze Strydonu, wydanych w trzech tomach w 1524 roku w bazylejskiej oficynie Jana Frobena. Pierwotnym posiadaczem woluminu był Jan Korzbok Witkowski (zm. 1572), którego superekslibrisami (herbowym i napisowym) opatrzono jej dolną okładzinę. Oprawę księgi wykonano w 1527 roku w warsztacie Macieja z Przasnysza (Mistrza Główek Anielskich). Jest ona stosunkowo wczesnym przykładem egzemplarza udekorowanego w typie architektonicznym z motywem portalu z tympanonem. Stanowi przy tym reprezentatywny przykład ukazujący wpływ introligatorstwa włoskiego na tę gałąź polskiego rzemiosła w pierwszej połowie XVI wieku.

Słowa kluczowe: Jan Korzbok Witkowski, Maciej z Przasnysza (Mistrz Główek Anielskich), Kraków, tegumentologia.

Oprawa stanowiąca przedmiot niniejszego komunikatu skrywa zbiór listów pióra św. Hieronima ze Strydonu, wydanych w trzech tomach w 1524 roku w słynnej oficynie bazylejskiego drukarza Jana Frobena ${ }^{2}$. Pierwszym właścicielem prezentowanej księgi był Jan Korzbok Witkowski (zm. 1572),

1 Praca powstała w ramach projektu grantowego: „Inwentaryzacja zasobu Archiwum Archidiecezjalnego w Gnieźnie: starodruki z Kolekcji Seminaryjnej Biblioteki Katedralnej i nowoodnalezione dokumenty papierowe konsystorza gnieźnieńskiego z XV i pocz. XVI w.", finansowanego z Narodowego Programu Rozwoju Humanistyki MNiSW (11H 160124 84), kierownik: dr hab. Piotr Pokora (Instytut Historii UAM w Poznaniu).

2 Archiwum Archidiecezjalne w Gnieźnie [dalej: AAG], sygn. BK 1507: Hieronim ze Strydonu, Opus epistolarum, t. 1-3, Basileae: Johann Froben, 1624. Wyrazy wdzięczności za wszelkie wsparcie przy pisaniu niniejszego tekstu niech zechce przyjać mgr Radosław Franczak. 
którego superekslibrisami (herbowym i napisowym) opatrzono jej dolną okładzinę. Ten pochodzący z możnej rodziny dziedzic podgnieźnieńskiego miasteczka Witkowo był krewnym prymasa Andrzeja Krzyckiego. Studiował na Akademii Krakowskiej oraz może również w Rzymie. W 1527 roku miał być proboszczem kaliskim oraz prawdopodobnie kanonikiem katedralnym płockim. W późniejszym czasie uzyskał szereg innych zaszczytnych godności kościelnych: prepozyturę kolegiaty św. Michała w Płocku, scholasterię płocka, dziekanię gnieźnieńską kanonię krakowską. Sławna była jego działalność budowlana oraz fundacyjna m.in. na rzecz Akademii Krakowskiej³.

Wpis własnościowy umieszczony na wyklejce górnej okładziny opisywanego woluminu wskazuje, że po śmierci duchownego wolumin ten przeszedł na własność parafii kościoła św. Mikołaja w Witkowie ${ }^{4}$. Obok zachowała się również słabo czytelna notka, mogąca wskazywać, że Witkowski (?) nabył omawiany wolumin za cenę trzech florenów. Kartę tytułową opatrzono z kolei częściowo wyciętą zapiską proweniencyjną w brzmieniu: „Andreae Słup[...]ii Gnesnen[sis] Cathalog[...] [insc]riptus[?] 1598vo" ${ }^{5}$. Wydawcą zbioru listów św. Hieronima był Erazm z Rotterdamu, którego imię znalazło się na każdej z trzech kart tytułowych. Co warte podkreślenia, zostało ono skrzętnie zakreślone na pierwszej z nich ${ }^{6}$.

Oprawę druku wykonano $\mathrm{z}$ fazowanych desek bukowych, które zostały powleczone brązową skórą. Fazowanie sprowadza się do ścięcia środkowej, wewnętrznej części krótszych krawędzi okładzin, czynności tej poddano również przeciwległą do grzbietu księgi, dłuższa, wewnętrzną krawędź ${ }^{7}$ Narożniki okładzin zaopatrzono w mosiężne okucia w formie

3 Zob. L. Łętowski, Katalog biskupów, prałatów i kanoników krakowskich, t. 3, Kraków 1852, s. 163; J. Korytkowski, Prałaci i kanonicy katedry metropolitalnej gnieźnieńskiej od roku 1000 aż do dni naszych. Podtug źródet archiwalnych, t. 3, Gniezno 1883, s. 532-536; W. Urban, Korzbok Witkowski Jan, w: Polski słownik biograficzny, t. 14, Wrocław 1968-1969, s. 160-161.

4 "post vitam [...] eccle[siae] Vitkovien[sis] [...]".

5 Wpis własnościowy nie zachował się w całości, ponieważ umieszczono go bezpośrednio przy wyciętym w późniejszym czasie sygnecie drukarskim Jana Frobena. Sygnet znajdujący się na końcu ostatniego z trzech tomów również został wycięty.

6 Wymienionego zabiegu dokonał późniejszy posiadacz księgi. Praktyka wtórnego cenzurowania druków, jeśli chodzi o „nieprawomyślnych” autorów czy wydawców (np. poprzez wycinanie sygnetów drukarskich), jest zjawiskiem stosunkowo powtarzalnym dla okresu kontrreformacji; zob. np. L. Grzebień, Organizacja bibliotek jezuickich w Polsce od XVI do XVIII wieku, "Archiwa Biblioteki i Muzea Kościelne” 1975 , t. 31, s. 252-253.

7 Na temat fazowania okładzin zob. J. Zamrzycka, Introligatorzy toruńscy od XV do XVI/XVII wieku. Typologia cech warsztatowych, Torun 2014, s. 31-32. 


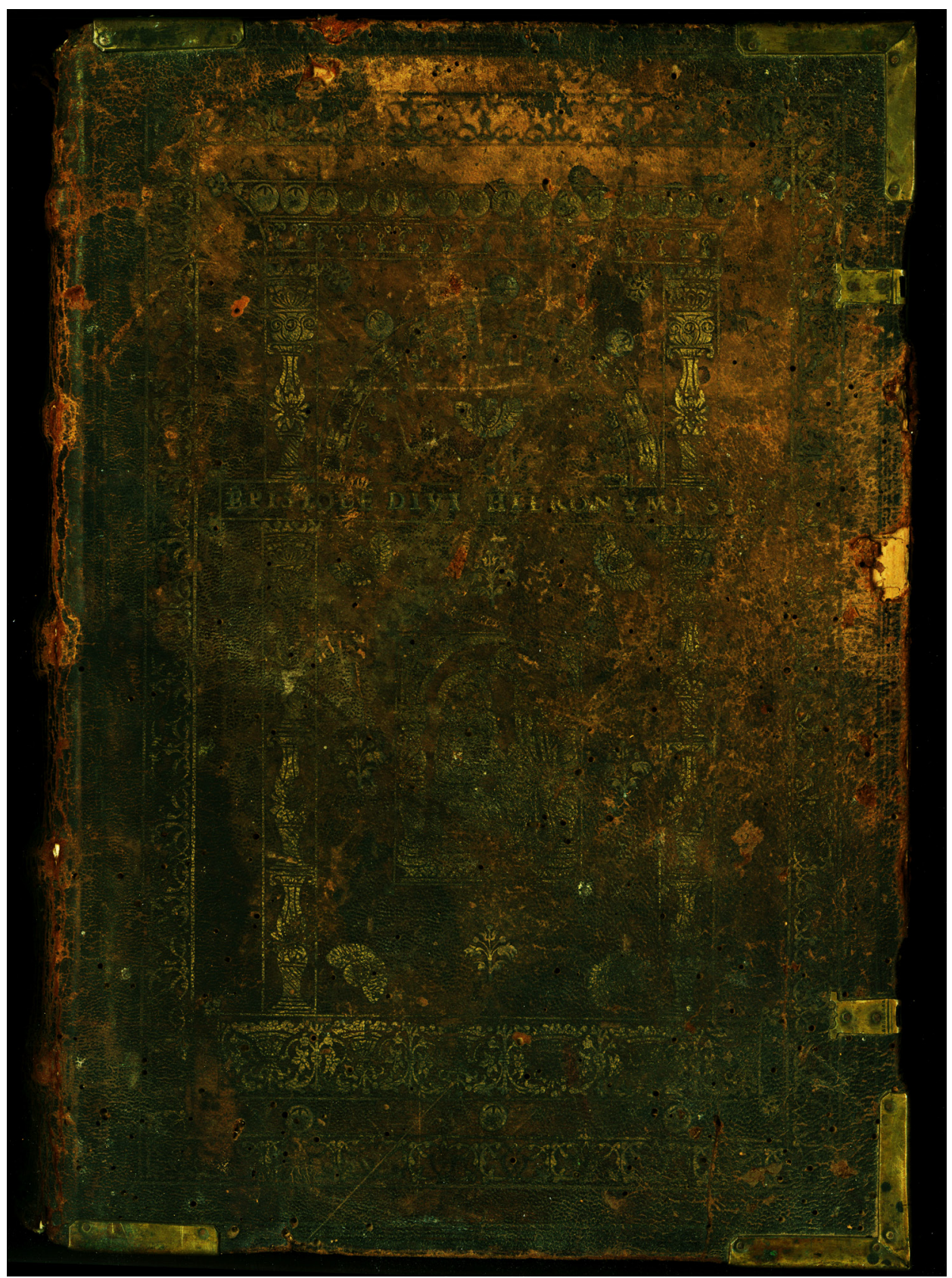

Il. 1. Oprawa druków z 1524 roku - górna okładzina, Maciej z Przasnysza (Mistrz Główek Anielskich), Kraków, 1527

Źródło: Archiwum Archidiecezjalne w Gnieźnie, fot. M. Macioszek. 


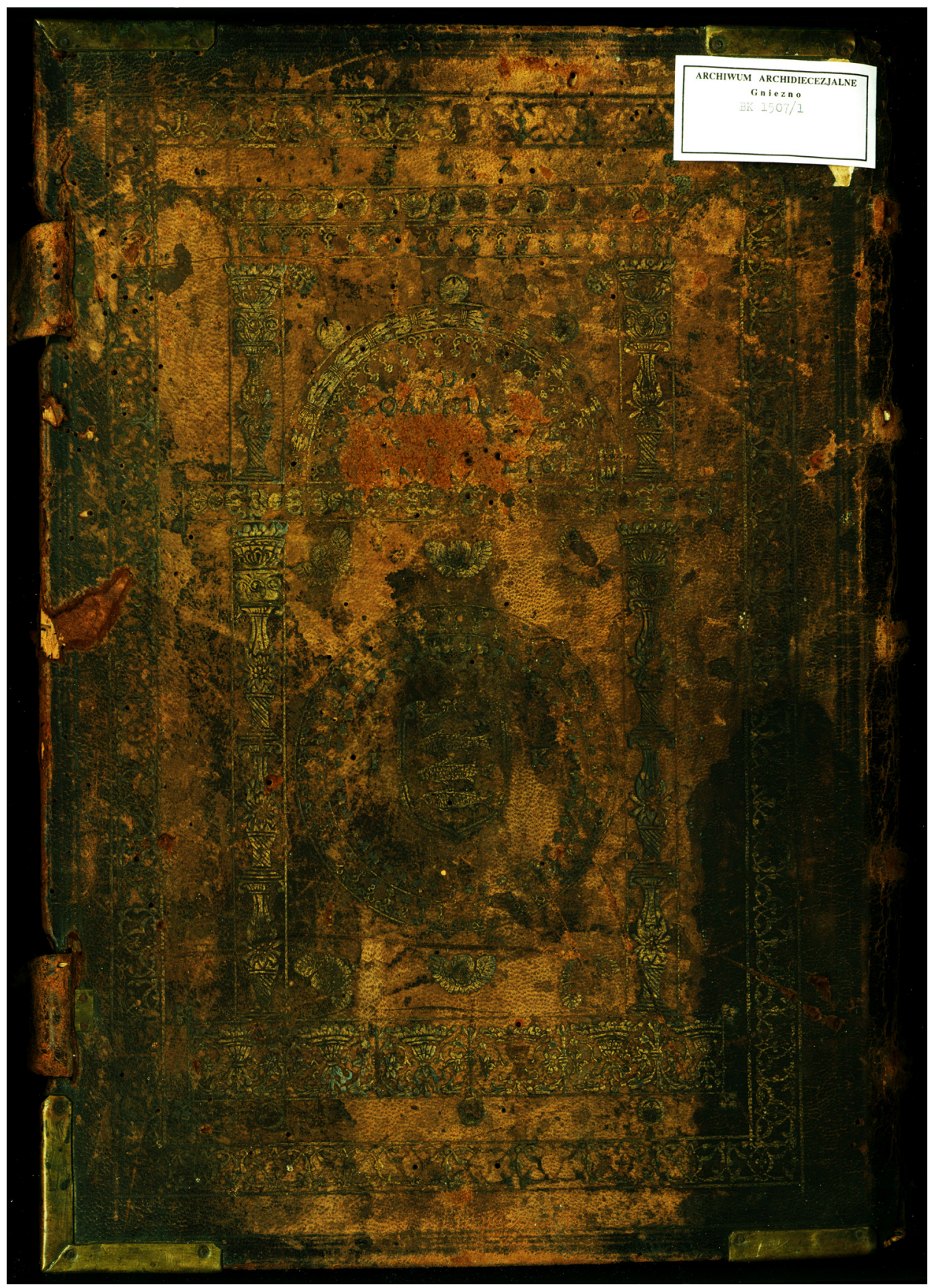

Il. 2. Oprawa druków z 1524 roku - dolna okładzina, Maciej z Przasnysza (Mistrz Główek Anielskich), Kraków, 1527

Źródło: Archiwum Archidiecezjalne w Gnieźnie, fot. M. Macioszek. 
pozbawionych dekoracji listew. Z kolei przy ich dłuższych brzegach przytwierdzono zapięcia mosiężno-skórzane, z których do dziś zachowały się jedynie zapinki okienkowe. Te ostatnie należy zaklasyfikować do typu „widełkowego" (zredukowany typ „ptasich główek”) z ornamentem geometrycznym ${ }^{8}$. Na dolnej okładzinie widoczne są prostokątne blaszki mocujące oraz szczątkowe fragmenty skórzanych pasków zaczepów. Blok książki scala pięć podwójnych zwięzów sznurowych, których niewielkie garby tworza, na nieznacznie zaokrąglonym grzbiecie, wyzbyte dekoracji kompartymenty. Zachowane w całości kapitałki zostały wyszyte kremową nicią. Księgę opatrzono papierowymi wyklejkami, na których widnieje filigran w postaci głowy wołu z siedmioramienną gwiazdą?

Niemal analogicznie rozplanowana dekoracja górnej oraz dolnej okładziny (il. 1 i 2), opracowana $w$ technice wycisku złoconego, wpisuje się w typ architektoniczny, który stanowi pochodną wpływów introligatorstwa włoskiego ${ }^{10}$. W tym przypadku zasadniczą rolę odgrywa motyw portalu wkomponowany w zewnętrzną ramę. Przedstawia on dwie stylizowane kolumny lub pilastry stojące na ornamentalnej podstawie, na których opierają się poprzeczna belka z umieszczonym w niej majuskułowym napisem tytułowym („EPISTOLE DIVI HIERONYMI STR”) oraz tympanon. Ten ostatni został wyznaczony dwustrefowym półkolem, składającym się z wiązek liści (od zewnątrz) oraz tzw. trójliści włoskich ${ }^{11}$ (od wewnątrz). Na okładzinie górnej pole tympanonu wzbogacono wyciskiem tłoka z motywem uskrzydlonej anielskiej główki. Dolna okładzina została $\mathrm{z}$ kolei opatrzona $\mathrm{w}$ tym miejscu, obecnie częściowo uszko-

${ }^{8}$ Inne zapinki tego typu por. np. A. Wagner, Oprawy ksiażkowe XIV-XVIII wieku w zbiorach Książnicy Kopernikańskiej w Toruniu, cz. 1, Rzeczpospolita, Prusy, Dolny Ślask. Katalog wystawy towarzyszacej III Ogólnopolskiej Konferencji Oprawoznawczej pt. "Zbiory polskie", Torun 2018, s. 50, 52, 58, 60, 88.

9 Zbliżony filigran por. https://www.piccard-online.de/detailansicht.php?klassi $=002.003 .004 \&$ ordnr=71521\&spiegeln=1 [dostęp: 23.02.2019].

${ }^{10}$ Zob. A. Wagner, Nieznana oprawa dla Jana Easkiego w Bibliotece Uniwersyteckiej w Poznaniu. Przyczynek do badań nad italianizmem w introligatorstwie polskim XVI wieku, „Biblioteka” 2012, nr 16, s. 44-46; idem, Włoskie wptywy w polskim introligatorstwie XV-XVI wieku, w: Tegumentologia polska dzisiaj, red. A. Wagner, Toruń 2015, s. 90-91; idem, Introligatorzy elit. O działalności Stanisława z Białej i Macieja z Przasnysza vel Mistrza Główek Anielskich, w: Introligatorzy i ich klienci, red. A. Wagner, Toruń 2017, s. 83-84; idem, Oprawa o dekoracji architektonicznej w zbiorach Biblioteki Kórnickiej. Przyczynek do dziejów italianizmu w renesansowym introligatorstwie Poznania i Krakowa, „Pamiętnik Biblioteki Kórnickiej" 2018, t. 35, s. 71-91.

11 Por. A. Wagner, Prymas Drzewicki jako bibliofil. W pięćsetlecie powstania pierwszego polskiego ekslibrisu, Warszawa 2016, s. 90, 102; idem, Superekslibris polski. Studium o kulturze bibliofilskiej i sztuce od średniowiecza do połowy XVII wieku, Toruń 2016, s. 209-212. 
dzonym, superekslibrisem napisowym Jana Witkowskiego. Składają się na niego wyciski literowe, które rozmieszczono $\mathrm{w}$ czterech wierszach: ,.D. \| IOANNIS || [...]E. || [...]LISI."12. Po obu stronach tympanonu znajdują się dwie znacznie krótsze kolumny lub pilastry, stanowiące podparcie dla umieszczonego wyżej gzymsu, ponad którym - w przypadku okładziny dolnej - wkomponowano datę wykonania oprawy: „1527”. Centrum prześwitu portalu, stanowiącego zwierciadło górnej okładziny, zajmuje słabo czytelny wycisk prostokątnej plakiety. Przedstawia on modlącego się na kolanach św. Hieronima, który trzyma w prawej dłoni kamień oraz spogląda na krucyfiks. Scena została ukazana pod łukiem renesansowej arkady, a całość obwiedziono linearną ramką strychulcową ${ }^{13}$. Niestety wycisk jest wytarty $\mathrm{w}$ dolnej strefie, $\mathrm{w}$ której można $\mathrm{z}$ trudnością dopatrzyć się potwierdzenia wymienionej identyfikacji w postaci lwa - atrybutu wskazanego ojca Kościoła ${ }^{14}$. Niemniej jeżeli jest ona poprawna, opisywany egzemplarz stanowi dobre exemplum, w którym można doszukiwać się hipotetycznej korelacji pomiędzy treścią drukowanego dzieła a dekoracją jego oprawy. Introligator, poza klasycznym napisem tytułowym, wzbogacił ją bowiem o starannie dobrane przedstawienie figuralne. W tym przypadku

12 Jeśliby przyjąć, że ostatni wyraz należy rozwinąć jako: „(CA)LIS(S)I(ENSIS)”, może on stanowić potwierdzenie, iż Witkowski był proboszczem kaliskim już w 1527 roku; por. W. Urban, op.cit., s. 160-161.

${ }^{13}$ Wydaje się, że za pomocą tej plakiety udekorowano dolną okładzinę oprawy księgi kanonika kujawskiego Piotra Izdbieńskiego (zm. 1528); zob. Biblioteka PTPN, sygn. 47941 IV; por. L. Dobrzyńska-Rybicka, Dwie wielkopolskie biblioteki klasztorne, "Zapiski Muzealne" 1917/1918, t. 2-3, s. 6-7; K. Rulka, Superekslibrisy w zbiorach Biblioteki Seminarium Duchownego we Włocławku, "Studia Włocławskie” 2003, t. 6, s. 554-555, przyp. 31. Za zwrócenie uwagi na ten wolumin składam podziękowanie Wojciechowi Grasiowi (Biblioteka PTPN) oraz mgr. Jakubowi Łukaszewskiemu (Biblioteka Uniwersytecka w Poznaniu). Wskazanym narzędziem ozdobiono również m.in. księgę należącą niegdyś do Piotra Wedeliciusza z Obornik (Biblioteka Jagiellońska [dalej: BJ], sygn. Medyc. 6600 IV); ołówkowe przerysy wycisków plakiet z wizerunkiem św. Hieronima, autorstwa Anny Lewickiej-Kamińskiej, wykonane z tego oraz innych egzemplarzy zob. BJ, sygn. Przyb. 77/80; Przyb. 79/80; Przyb. 80/80; Przyb. 81/80. Por. także B. Nuska, Polski wpływ na formowanie się czeskiej renesansowej oprawy ksią̇̇kowej, „Ze Skarbca Kultury. Biuletyn informacyjny Zakładu Narodowego im. Ossolińskich" 1964, t. 16, s. 158 oraz ryc. 10; A. Wagner, Oprawa o dekoracji architektonicznej..., il. 9b.

14 Por. np. M. Jacniacka, Hieronim. Ikonografia, w: Encyklopedia katolicka, t. 6, Lublin 1993, kol. 853-856. Zestawienie wycisków „krakowskich” plakiet ze św. Hieronimem zob. M. Krynicka, Elementy figuralne dekoracji polskich opraw ksiązkowych $i$ ich związki z grafika w pierwszym trzydziestoleciu XVI wieku, w: Dawna książka i kultura. Materiaty międzynarodowej sesji naukowej z okazji pięćsetlecia sztuki drukarskiej w Polsce, red. S. Grzeszczuk, A. Kawecka-Gryczowa, Wrocław 1975, s. 181, przyp. 21. 
wizerunek św. Hieronima, wkomponowany w motyw portalu, zaprasza niejako do „wejścia” w lekturę pięknie oprawnej księgi, informując zarazem czytelnika o jej zawartości ${ }^{15}$. Wewnętrzne narożniki ramy tworzącej zwierciadło wzbogacono, wspomnianym wyżej, motywem uskrzydlonej główki anielskiej. Zwierciadło okładziny dolnej zdobi z kolei superekslibris Witkowskiego. Przedstawia on tarczę herbową z dwoma wcięciami i wolutowym spięciem nasady oraz szpicem w podstawie ${ }^{16}$, na której umieszczono godło herbu Korzbok. Towarzyszą jej inicjały właściciela: "I[oannes] K[orzbok]". Tarczę otacza charakterystyczny okrągły wieniec, który składa się z tzw. trójliści włoskich ujętych w linearne pierścienie ${ }^{17}$. Wieniec od wewnątrz wzbogacaja przylegające doń, liczne wyciski tłoka (tłoków?) z motywem tzw. listka aldyńskiego. Ponadto w pole zwierciadła wkomponowano sześć uskrzydlonych główek anielskich. Całość dekoracji okładzin dopełniają wyciski tłoków z motywem okrągłego owocu, trójlistka, kwiatonu i listka aldyńskiego.

$Z$ racji tego, że opisywany egzemplarz wykonano w 1527 roku, stanowi on na rodzimym gruncie stosunkowo wczesny przykład realizacji oprawy $\mathrm{w}$ typie architektonicznym $\mathrm{z}$ motywem portalu ${ }^{18}$. Analiza jego dekoracji pozwala na wysunięcie przypuszczenia, że został wykonany w przodującym wówczas ośrodku krakowskim. Wskazane byłoby przy tym atrybuować go do warsztatu Macieja z Przasnysza (Mistrza Główek

${ }^{15}$ Warto odnotować, że w odniesieniu do innych opraw, które także pochodzą z warsztatu Macieja z Przasnysza (Mistrza Główek Anielskich), dojrzeć można korespondencyjność zachodzącą pomiędzy pierwotnymi posiadaczami ksiąg (Piotrem Izdebieńskim, Piotrem Wedeliciuszem) a wyciśniętą na oprawach plakietą z pełnopostaciowym przedstawieniem ich patrona - św. Piotra (zob. Biblioteka PTPN, sygn. 47941 IV; BJ, sygn. Medyc. 6600 IV; por. np. L. Dobrzyńska-Rybicka, op.cit., ryc. 10b; J. Storm van Leeuwen, The Golden Age of Bookbindings in Cracow, 1400-1600, Kraków 2011, s. 114-115; A. Wagner, Superekslibris polski..., tabl. VI). Analiza ikonograficzna innych egzemplarzy z wymienionej pracowni pozwoli w przyszłości być może na potwierdzenie bądź też zanegowanie postawionej tu hipotezy. Prawdopodobne jest bowiem, że rzemieślnik kierował się wypracowanym schematem i we wskazanych przykładach można mówić jedynie o czystej przypadkowości. Podobna, choć nieco późniejszą zależność między imieniem właściciela a wizerunkiem jego patrona da się zaobserwować, jeśli chodzi o oprawy należące do dominikanina Pawła Sarbiniusa (zm. 1563); zob. R. Franczak, Oprawa "Homiliarum" z pełnopostaciowym wyciskiem radełka jagiellońskiego w zbiorach Archiwum Archidiecezjalnego w Gnieźnie, "Biblioteka” 2016, nr 20, s. 55-69; por. także A. Wagner, Oprawa o dekoracji architektonicznej..., s. 79.

${ }^{16}$ Por. A. Wagner, Superekslibris polski..., s. 263-264.

17 Por. A. Wagner, Prymas Drzewicki..., s. 90; idem, Superekslibris polski..., s. 209-212.

18 Zob. A. Wagner, Nieznana oprawa..., s. 44 oraz il. 10; idem, Superekslibris polski..., s. 212 oraz tabl. VI. 
Anielskich) ${ }^{19}$. Badania Marii Krynickiej i Arkadiusza Wagnera ujawniły szereg opraw w typie architektonicznym, pochodzących z pracowni wskazanego rzemieślnika, które należały do osób zaliczanych do najwybitniejszych polskich miłośników książki doby renesansu. Wśród person zasługujących na takie miano wymienić należy chociażby reformatora religijnego Jana Łaskiego (Młodszego) ${ }^{20}$, biskupa krakowskiego Piotra Tomickiego ${ }^{21}$, królewskiego lekarza Piotra Wedeliciusza z Obornik czy archidiakona poznańskiego i gnieźnieńskiego Macieja Śliwnickiego ${ }^{22}$. Warto przypomnieć, że ten ostatni był głównym oponentem Witkowskiego w głośnym sporze o dziekanię gnieźnieńską ${ }^{23}$. Należy również nadmienić, że z usług Stanisława z Białej - introligatora blisko związanego z Maciejem z Przasnysza - korzystał wspomniany wyżej protektor i krewny właściciela omawianego woluminu - Andrzej Krzycki ${ }^{24}$.

Witkowski zlecił oprawienie prezentowanej księgi w czasie, w którym rozpoczynał swoją karierę duchowną. Rodzi się zatem pytanie, czy mamy tutaj do czynienia $z$ jednym $z$ wielu podobnych zamówień, czy może tylko z jednorazowym wydatkiem? Niemniej zlecenie wykonania kosztownej oprawy może świadczyć o daleko idących aspiracjach bibliofilskich oraz dobrym wyczuciu trendów panujących wówczas w kręgu elit państwowo-kościelnych. Identyfikacja kolejnych książek, stanowiących niegdyś własność gnieźnieńskiego dziekana, mogłaby potwierdzić postawioną tu tezę bądź jej zaprzeczyć. Wydaje się, że oprawa będąca przedmiotem niniejszego komunikatu uzupełnia stosunkowo licznie zachowany zbiór obiektów przypisywanych w literaturze przedmiotu krakowskiemu warsztatowi Macieja z Przasnysza (Mistrza Główek

${ }^{19}$ Na temat Macieja z Przasnysza (Mistrza Główek Anielskich) oraz jego introligatorskiej twórczości zob. np. Sztuka w Krakowie w latach 1350-1550. Wystawa urzadzona w sześćsetletnia rocznice założenia Uniwersytetu Jagiellońskiego, Kraków 1964, nr 255-256 (opisy M. Krynicka); M. Krynicka, op.cit., s. 169-183; A. Wagner, Nieznana oprawa..., s. 39-40; P. Pokora, Pontificale Romanum z 1520 roku z biblioteki prymasa Macieja Drzewickiego. O odnalezieniu jednego z zaginionych klejnotów Biblioteki Katedralnej w Gnieźnie, „Biblioteka” 2013, nr 17, s. 37-51; P. Pokora, M. Muraszko, Skarby drukarstwa i introligatorstwa ze zbiorów dawnej Biblioteki Katedralnej w Gnieźnie. Katalog wystawy w Bibliotece Raczyńskich, Poznań 5-30 maja 2015, Poznań-Gniezno 2015, s. 15; A. Wagner, Włoskie wptywy..., s. 88-91; idem, Introligatorzy elit..., s. 73-92; idem, Oprawa o dekoracji architektonicznej..., s. 78-80.

20 A. Wagner, Introligatorzy elit..., s. 327.

21 Ibidem, s. 82.

${ }^{22}$ Zob. J. Storm van Leeuwen, op.cit., s. 114-115; A. Wagner, Superekslibris polski..., tabl. VI; A. Wagner, Oprawa o dekoracji architektonicznej..., il. $9 \mathrm{~b}$.

23 Zob. przyp. 3.

${ }^{24}$ A. Wagner, Prymas Drzewicki..., s. 40-41. 
Anielskich), stanowiąc jednocześnie dość wczesny przykład egzemplarza udekorowanego $\mathrm{w}$ typie architektonicznym $\mathrm{z}$ motywem portalu $\mathrm{z}$ tympanonem.

\section{Bibliografia}

Źródła

Archiwum Archidiecezjalne w Gnieźnie, sygn. BK 1507.

Biblioteka Jagiellońska, sygn. Medyc. 6600 IV; Przyb. 77/80; Przyb. 79/80; Przyb. 80/80; Przyb. 81/80.

Biblioteka Poznańskiego Towarzystwa Przyjaciół Nauk, sygn. 47941 IV.

Bazy online

https://www.piccard-online.de [dostęp: 23.02.2019]

Opracowania

Dobrzyńska-Rybicka L., Dwie wielkopolskie biblioteki klasztorne, „Zapiski Muzealne" 1917/1918, t. 2-3, s. 3-29.

Franczak R., Oprawa "Homiliarum" z petnopostaciowym wyciskiem radełka jagiellońskiego w zbiorach Archiwum Archidiecezjalnego w Gnieźnie, „Biblioteka” 2016, nr 20, s. 55-69.

Grzebień L., Organizacja bibliotek jezuickich w Polsce od XVI do XVIII wieku, „Archiwa Biblioteki i Muzea Kościelne" 1975, t. 31, s. 226-281.

Jacniacka M., Hieronim. Ikonografia, w: Encyklopedia katolicka, t. 6, Lublin: Wydawnictwo Towarzystwa Naukowego Katolickiego Uniwersytetu Lubelskiego 1993, kol. 853-856.

Korytkowski J., Prałaci i kanonicy katedry metropolitalnej gnieźnieńskiej od roku 1000 aż do dni naszych. Podtug źródeł archiwalnych, t. 3, Gniezno: Nakładem i drukiem J.B. Langiego 1883.

Krynicka M., Elementy figuralne dekoracji polskich opraw ksiażkowych $i$ ich zwiazki z grafika w pierwszym trzydziestoleciu XVI wieku, w: Dawna ksiażka i kultura. Materiały międzynarodowej sesji naukowej z okazji pięćsetlecia sztuki drukarskiej w Polsce, red. S. Grzeszczuk, A. Kawecka-Gryczowa, Wrocław: Zakład Narodowy im. Ossolińskich 1975.

Łętowski L., Katalog biskupów, prałatów i kanoników krakowskich, t. 3, Kraków: Drukarnia Uniwersytetu Jagiellońskiego 1852.

Nuska B., Polski wpływ na formowanie się czeskiej renesansowej oprawy ksiażkowej, "Ze Skarbca Kultury. Biuletyn informacyjny Zakładu Narodowego im. Ossolińskich" 1964, t. 16, s. 132-186.

Pokora P., Pontificale Romanum z 1520 roku z biblioteki prymasa Macieja Drzewickiego. O odnalezieniu jednego z zaginionych klejnotów Biblioteki Katedralnej w Gnieźnie, „Biblioteka” 2013, nr 17, s. 37-51. 
Pokora P., Muraszko M., Skarby drukarstwa i introligatorstwa ze zbiorów dawnej Biblioteki Katedralnej w Gnieźnie. Katalog wystawy w Bibliotece Raczyńskich, Poznań 5-30 maja 2015, Poznań - Gniezno: Instytut Historii UAM 2015.

Rulka K., Superekslibrisy w zbiorach Biblioteki Seminarium Duchownego we Włocław$k u$, „Studia Włocławskie” 2003, t. 6, s. 527-557.

Storm van Leeuwen J., The Golden Age of Bookbindings in Cracow, 1400-1600, Kraków: Biblioteka Jagiellońska 2011.

Sztuka w Krakowie w latach 1350-1550. Wystawa urzadzona w sześćsetletnia rocznice założenia Uniwersytetu Jagiellońskiego, Kraków: Muzeum Narodowe 1964.

Urban W., Korzbok Witkowski Jan, w: Polski słownik biograficzny, t. 14, Wrocław: Wydawnictwo Zakładu Narodowego im. Ossolińskich 1968-1969, s. 160-161.

Wagner A., Introligatorzy elit. O działalności Stanisława z Białej i Macieja z Przasnysza vel Mistrza Główek Anielskich, w: Introligatorzy i ich klienci, red. A. Wagner, Toruń: Wydawnictwo Naukowe Uniwersytetu Mikołaja Kopernika 2017, s. 73-92.

Wagner A., Nieznana oprawa dla Jana Łaskiego w Bibliotece Uniwersyteckiej w Poznaniu. Przyczynek do badań nad italianizmem w introligatorstwie polskim XVI wieku, „Biblioteka” 2012, t. 16, s. 23-57.

Wagner A., Oprawa o dekoracji architektonicznej w zbiorach Biblioteki Kórnickiej. Przyczynek do dziejów italianizmu w renesansowym introligatorstwie Poznania i Krakowa, „Pamiętnik Biblioteki Kórnickiej” 2018, t. 35, s. 71-91.

Wagner A., Oprawy książkowe XIV-XVIII wieku w zbiorach Książnicy Kopernikańskiej w Toruniu, cz. 1, Rzeczpospolita, Prusy, Dolny Śląs. Katalog wystawy towarzyszacej III Ogólnopolskiej Konferencji Oprawoznawczej pt. "Zbiory polskie”, Toruń: Wojewódzka Biblioteka Publiczna - Książnica Kopernikańska w Toruniu 2018.

Wagner A., Prymas Maciej Drzewicki jako bibliofil. W pięćsetlecie powstania pierwszego polskiego ekslibrisu, Warszawa: Urząd Gminy i Miasta Drzewica 2016.

Wagner A., Superekslibris polski. Studium o kulturze bibliofilskiej i sztuce od średniowiecza do połowy XVII wieku, Torun: Wydawnictwo Naukowe Uniwersytetu Mikołaja Kopernika 2016.

Wagner A., Włoskie wpływy w polskim introligatorstwie XV-XVI wieku, w: Tegumentologia polska dzisiaj, red. A. Wagner, Toruń: Wydawnictwo Naukowe Uniwersytetu Mikołaja Kopernika 2015, s. 81-106.

Zamrzycka J., Introligatorzy toruńscy od XV do XVI/XVII wieku. Typologia cech warsztatowych, Toruń: Wydawnictwo Adam Marszałek 2014. 
MICHAŁ MURASZKO

\title{
Cracow binding of the book formerly in possession of Jan Korzbok Witkowski from the collections of the Archdiocesan Archives in Gniezno
}

\begin{abstract}
This paper discusses the binding of a set of letters of St. Hieronimus of Strydon, published in three volumes in the printing office of Jan Froben in Basel in 1524. The original owner of the volume was Jan Korzbok Witkowski (d. 1572), whose supralibros indicating the ownership of a book (and bearing his coat of arms and an inscription) was added to the bottom of the front cover page. The original book binding was done in 1527 in the workshop of Maciej of Przasnysz (also known as the Master of Angels Heads). It is a relatively early example of a copy embellished with architectural elements with the motif of a portico with arched tympanum. The binding is a representative example of the book binding technique that shows the influence of Italian book bindery on this particular craft in Poland in the first half of the sixteenth century.
\end{abstract}

Keywords: Jan Korzbok Witkowski; Maciej of Przasnysz (Master of Angels Heads); Kraków; tegumentology.

Tekst wpłynął do Redakcji 12 maja 2019 roku. 
